\title{
FURTHER INVESTIGATIONS ON POPULATIONS OF THE DEEP-WATER BLUE AND RED SHRIMP ARISTEUS ANTENNATUS (RISSO, 1816) (DECAPODA, DENDROBRANCHIATA), AS INFERRED FROM AMPLIFIED FRAGMENT LENGTH POLYMORPHISM (AFLP) AND MTDNA ANALYSES
}

\author{
BY
}

\author{
SABRINA LO BRUTTO ${ }^{1,3}$ ), TERESA MAGGIO ${ }^{1}$ ), ANNA MARIA DEIANA ${ }^{2}$ ), \\ RITA CANNAS $^{2}$ ) and MARCO ARCULEO ${ }^{1}$ ) \\ 1) Dipartimento di Biologia Ambientale e Biodiversità, Università di Palermo, \\ Via Archirafi 18, I-90123 Palermo, Italy \\ 2 ) Dipartimento di Scienze della Vita e dell' Ambiente, Università di Cagliari, \\ Via Tommaso Fiorelli, I-09126 Cagliari, Italy
}

\begin{abstract}
The aim of this study was to integrate existing mitochondrial DNA data relating to the deepsea blue and red shrimp Aristeus antennatus (Risso, 1816) with data obtained by Amplified Fragment Length Polymorphism (AFLP). A total of 145 AFLP polymorphic loci were scored in 236 specimens collected from one Atlantic and seven Mediterranean sample sites. AMOVA results revealed that the overall genetic variation among-populations was lower $(11.81 \%)$ than withinpopulations $(88.19 \%)$. The genetic variation between the Atlantic and Mediterranean samples was found to be not significant $\left(\Phi_{\mathrm{CT}}=-0.007\right.$; N.S.), indicating that the transition area between the Atlantic Ocean and the Mediterranean Sea does not act as a barrier to gene flow. Bayesian analysis also demonstrated the absence of genetic differentiation between the Atlantic and Mediterranean populations and within the Mediterranean basin. The results are in agreement with those previously published using mitochondrial markers. Some considerations on the life history traits of the species are discussed.
\end{abstract}

Key words. - AFLP, mtDNA, Aristeus antennatus, Atlanto-Mediterranean region

\section{RIASSUNTO}

Lo scopo del lavoro è stato quello di integrare dati precedenti ottenuti dall'analisi del DNA mitocondriale nel gambero viola Aristeus antennatus (Risso, 1816) con dati ottenuti dall'analisi di un marcatore nucleare (Amplified Fragment Length Polymorphism, AFLP). In totale sono stati identificati 145 loci polimorfici AFLP in 236 esemplari raccolti da sette località del Mediterraneo e da un sito dell'Oceano Atlantico. I risultati dell'analisi AMOVA hanno rivelato che la variazione genetica tra le popolazioni è inferiore $(11,81 \%)$ alla variazione intra-popolazionale $(88,19 \%)$. Il

3) e-mail: sabrina.lobrutto@unipa.it

(C) Koninklijke Brill NV, Leiden, 2012 
livello di variazione genetica tra l'Atlantico e i campioni mediterranei è risultato non significativo $\left(\Phi_{\mathrm{CT}}=-0,007\right.$; N.S.), mostrando l'assenza di "punti di rottura" associati all' area di transizione tra l'Oceano Atlantico e il Mar Mediterraneo. L'analisi bayesiana ha ulteriormente supportato l'assenza di differenziazione genetica tra l'Atlantico e le popolazioni del Mediterraneo, e tra le popolazioni mediterranee. Questi risultati sono in accordo con quelli precedentemente pubblicati e ricavati dall'analisi di marcatori mitocondriali. Vengono discusse le caratteristiche biologiche della specie e il pattern di omogeneità intraspecifica.

Parole chiave. - AFLP, mtDNA, Aristeus antennatus, Area atlanto-mediterranea

\section{INTRODUCTION}

The interactions between oceanographic conditions and biological characteristics of a species, for instance the dispersal capability, make the use of different molecular markers essential for understanding the causes of the inter-population structure of marine taxa. The more slowly evolving and conservative markers typically indicate older processes that have affected the genetic structure of the species; in contrast, rapidly evolving and highly polymorphic markers can help to hypothesize more recent mechanisms, processes or events. Thus, markers evolving at different rates provide information relating to different time/space scales; and this explains why, in detecting effective genetic intra-species architecture, markers with different properties are used, irrespective of the species studied. This has been widely demonstrated by the large number of articles that involve species of commercial interest: e.g., Merluccius merluccius L., 1758 (cf. Lo Brutto et al., 2004); Solea vulgaris Quensel, 1806 (cf. Garoia et al., 2007); Salmo trutta L., 1758 (cf. Lo Brutto et al., 2010; Apostolidis et al., 2011).

Over the past two decades, many researchers have studied the biology, ecology and the exploitation levels of one of the most important of the Mediterranean fishery resources, the deep-water blue and red shrimp Aristeus antennatus (Risso, 1816) (cf. Demestre \& Lleonard, 1993; Cartes, 1994; Arculeo et al., 1995; Ragonese \& Bianchini, 1996; Kapiris \& Thessalou-Legaki, 2001, 2006; Cau et al., 2002; Arculeo et al., 2011). Aristeus antennatus is distributed throughout the Mediterranean Sea, with the exception of the Adriatic Sea (Holthuis, 1980), and along the eastern Atlantic coast to the Cape Verde Islands (Ribeiro-Cascalho \& Arrobas, 1982), and in the Indian Ocean (Crosnier, 1978). It has a wide bathymetric distribution, occurring at depths between 200 and 3300 m (Sardà et al., 2004) and is usually caught by trawlers on muddy bottoms at depths between 400 and $800 \mathrm{~m}$. The presence of younger fractions of the population living at depths inaccessible to trawlers, called virgin grounds, reduces the effect of overexploitation of this species (Sardà et al., 1994; Sardà \& Cartes, 1997; Papaconstantinou \& Kapiris, 2001). In fact, A. antennatus has been intensively trawled in the deep sea for 
more than 70 years as target species of a mono-specific fishery; nonetheless the Mediterranean populations of the blue and red shrimp have not collapsed (Caddy, 1999; Roberts, 2002; Morato et al., 2006; Company et al., 2008; Maiorano et al., 2010).

Recently, some authors demonstrated that the population dynamics of A. antennatus are strictly linked to the environmental conditions of its deep-sea habitat, in terms of climatic events, hydrographic factors and trophic resources (Cartes, 1994; Company et al., 2008; Guijarro et al., 2008; Maynou, 2008; Lo Brutto et al., 2011), thereby suggesting that this species merits attention.

Studies regarding stock delimitations were initially performed through morphometric and allozyme analyses by Sardà et al. (1998). Morphometric parameters revealed that populations from different parts of the Mediterranean and the adjacent Atlantic area were significantly different; conversely, allelic frequencies indicated low levels of differentiation among the same samples. More recently, various authors have analysed the genetic variation of mitochondrial (mt) DNA and demonstrated no strong population differentiation, neither along a depth gradient in the western Mediterranean (Sardà et al., 2010; Cannas et al., 2012) nor along the Atlantic Ocean-western Mediterranean-eastern Mediterranean axis (Maggio et al., 2009; Roldán et al., 2009; Fernández et al., 2011). All studies concur with the absence of a divergent genetic partition in the Mediterranean, attributed to the species' biology, particularly to its high dispersion capability, and to the effects of prevailing marine currents (Maggio et al., 2009; Roldán et al., 2009; Sardà et al., 2010; Fernández et al., 2011).

The aim of this study was to improve the data relating to the genetic variation of A. antennatus in a sampling area ranging from the Mediterranean to the adjacent waters of the Atlantic, using two differently evolving molecular markers (nuclear AFLP and mitochondrial control region), bearing in mind that AFLP, together with other markers, can provide more robust and comprehensive estimates of the genetic population structure as already demonstrated for other species (Lu et al., 2000; Weetman et al., 2007).

\section{MATERIAL AND METHODS}

The specimens of Aristeus antennatus from the Mediterranean Sea, analysed here with AFLP, originating from the Algero-Provençal, the Tyrrhenian Sea and the Strait of Sicily (see table I), were captured and analysed by means of mtDNA sequencing by Maggio et al. (2009). Furthermore, a sample from the Atlantic Ocean was collected close to Faro in southern Portuguese waters (fig. 1 and table I).

The Atlantic sample was analysed here for the first time by direct sequencing of a 369-bp mtDNA control region fragment and included in the mitochondrial 
TABLE I

AFLP and mtDNA analysis: site locations, codes and number of the analysed specimens of Aristeus antennatus (Risso, 1816)

\begin{tabular}{llllcc}
\hline $\begin{array}{l}\text { Geographical } \\
\text { region }\end{array}$ & Sub-basin & Site location & Code & \multicolumn{2}{c}{ Sample size } \\
\cline { 3 - 5 } & & & AFLP & mtDNA \\
\hline $\begin{array}{c}\text { Atlantic Ocean } \\
\text { Mediterranean } \\
\text { Sea }\end{array}$ & Algero-Provençal & Faro (Portugal) & ATL & 46 & 46 \\
& & Cataluña (north-western Spain) & CA & 30 & 14 \\
& & Sanremo (north-western Italy) & SR & 30 & 28 \\
& & Santa Margherita Ligure & SM & 15 & 26 \\
& (north-western Italy) & & & \\
& Sant'Antioco & SW-SA & 30 & 22 \\
& Tyrrhenian & South-western Sardinia Island) & & & \\
& & Siniscola (north-eastern & NE-SA & 27 & 8 \\
& Sardinia Island) & & & \\
& Strait of Sicily & Serrasini (northern Sicily Island) & TE & 30 & 29 \\
& Strait of Sicily & SS & 28 & 19 \\
& (southern Sicily Island) & & & \\
\hline
\end{tabular}

Mediterranean Sea specimens previously sequenced and analysed by using mtDNA in Maggio et al. (2009).

dataset previously published by Maggio et al. (2009). Analysis of mitochondrial diversity was done with DNASP (ver. 5) software (Librado \& Rozas, 2009).

The AFLP analysis was performed in accordance with the description given by Vos et al. (1995). Restriction digests were carried out in 40- $\mu 1$ reactions, using $200 \mathrm{ng}$ of genomic DNA, $5 \mathrm{U}$ TaqI, $5 \mathrm{U}$ EcoRI and $1 \times$ RL buffer $(50 \mathrm{mM}$ TrisHAc, $50 \mathrm{mM} \mathrm{MgCl} 2,250 \mathrm{mM} \mathrm{KAc}, 25 \mathrm{mM}$ DTT, $25 \mathrm{ng} / \mu \mathrm{l} \mathrm{BSA}$ ) for $1 \mathrm{~h}$ at $65^{\circ} \mathrm{C}$ and $1 \mathrm{~h}$ at $37^{\circ} \mathrm{C}$. After digestion, $9 \mu \mathrm{l}$ of ligation solution, including $5 \mathrm{pmol}$ EcoRI adaptor and 50 pmol TaqI adaptor, 1 U T4 ligase, $1 \times$ RL buffer RL and $10 \mathrm{mM}$ ATP was added to the restricted DNA solution followed by incubation at $37^{\circ} \mathrm{C}$. Pre-selective amplification was performed in $50 \mu \mathrm{l}$ of reaction sample containing $5 \mu \mathrm{l}$ of diluted ligation mixture, $75 \mathrm{ng} / \mu \mathrm{l}$ of pre-amplification primers with a single selective base, $10 \mathrm{mM}$ dNTPs, $1 \times$ PCR buffer, $25 \mathrm{mM} \mathrm{MgCl}_{2}$ and $0.2 \mathrm{U}$ Taq DNA polymerase. Temperature cycles followed this protocol: initial denaturation at $95^{\circ} \mathrm{C}$ for $15 \mathrm{~s}$, then 20 cycles of $94^{\circ} \mathrm{C}$ for $30 \mathrm{~s}, 56^{\circ} \mathrm{C}$ for $30 \mathrm{~s}$ and $72^{\circ} \mathrm{C}$ for $60 \mathrm{~s}$, followed by a final extension of $10 \mathrm{~min}$ at $72^{\circ} \mathrm{C}$. The selective amplification reaction was performed in $10 \mu \mathrm{l}$ containing $1 \mu \mathrm{l}$ of pre-selective product diluted 20 -fold in distilled water, $10 \mu \mathrm{M}$ of selective primers with three selective bases, $10 \mathrm{mM}$ dNTPs, $1 \times$ PCR buffer, $25 \mathrm{mM} \mathrm{MgCl}_{2}$ and $0.2 \mathrm{U}$ Taq DNA polymerase. Selective amplification was performed with $15 \mathrm{~s}$ denaturation at $95^{\circ} \mathrm{C}$, then 11 cycles of $30 \mathrm{~s}$ at $94^{\circ} \mathrm{C}, 30 \mathrm{~s}$ at $65^{\circ} \mathrm{C}$ and $1 \mathrm{~min}$ at $72^{\circ} \mathrm{C}$, with a $0.5^{\circ} \mathrm{C}$ decrease in the annealing temperature each cycle, followed by 23 cycles of $30 \mathrm{~s}$ at $94^{\circ} \mathrm{C}, 30 \mathrm{~s}$ at $56^{\circ} \mathrm{C}$ and $1 \mathrm{~min}$ at $72^{\circ} \mathrm{C}$, with a final extension of $10 \mathrm{~min}$ at $60^{\circ} \mathrm{C}$. 

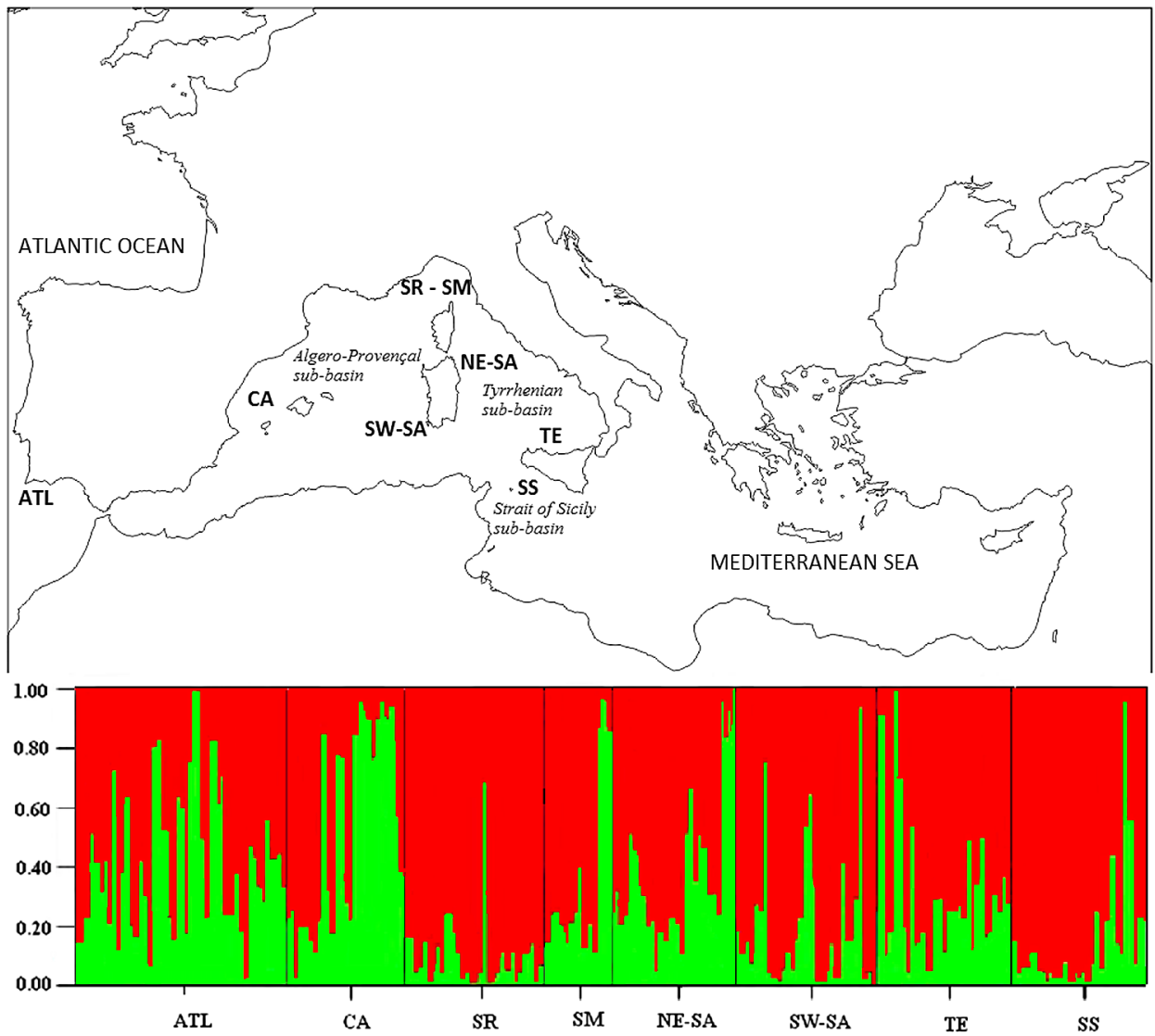

Fig. 1. Top, sampling sites of Aristeus antennatus (Risso, 1816) in the Atlanto-Mediterranean region: 1, Faro, Portugal (ATL); 2, Cataluña (CA), north-western Spain; 3, Sanremo (SR); and, 4, Santa Margherita Ligure (SM) in north-western Italy; 5 and 6, Siniscola (NE-SA) and Sant'Antioco (SWSA) in the north-eastern and south-western Sardinia, respectively; 7 and 8, Terrasini (TE) and Strait of Sicily (SS), northern and southern Sicily, respectively. Bottom, summary plot of $q$ estimates (proportion of membership) for $K=2$ from the AFLP analysis. This figure is published in colour in the online edition of this journal, which can be accessed via http://booksandjournals.brillonline.

com/content/15685403.

Twelve primer pairs were analysed and five selective primer combinations were chosen to generate all AFLP profiles: EcoRI-AAA + TaqI-AGG, EcoRI-AAA + TaqI-ATG, EcoRI-AAA + TaqI-ACA, EcoRI-ATT + TaqI-AGG and EcoRIATT + TaqI-ATG. Selective PCR products were separated on an ABI PRISM 310 automated sequencer (Applied Biosystems) with a GeneScan Rox 500 internal size standard. Electropherograms were subsequently analysed using Genescan 2.02 and Genotyper 2.5 (Applied Biosystem).

The percentage of polymorphic loci (5\% level) and unbiased estimates of genetic diversity were computed using AFLP-Surv 1.0 software with a non- 
uniform prior distribution of allele frequencies (Vekemans et al., 2002). Allelic frequencies at AFLP loci were calculated from the observed frequencies of the fragments using the Bayesian approach, as proposed by Zhivotovsky (1999) for diploid species. Statistics relating to gene diversity were computed, using AFLP-Surv 1.0 software, strictly following the treatment proposed by Lynch \& Milligan (1994). Total gene diversity $H_{\mathrm{T}}(\mathrm{Nei}, 1987)$ was calculated by pooling all individuals in a population; considering each population, $H_{\mathrm{E}}$, Nei's gene diversity within-population, was also computed; total variance of $H_{\mathrm{E}}$ was subdivided into the variance due to sampling of individuals, $\operatorname{Var} I$, and the variance due to sampling of loci VarL. Finally, $H_{\mathrm{S}}$ was calculated as the average within-population Nei gene diversity and its variance subdivided into $\operatorname{Var}$ (due to sampling of individuals), $\operatorname{VarL}$ (due to sampling of loci) and $\operatorname{Var} \mathrm{P}$ (due to sampling of populations).

Identification of outlier loci was carried out in accordance with the approaches of Beaumont \& Nichols (1996) and Beaumont \& Balding (2004), as implemented in the DFDIST software (http://www.rubic.rdg.ac.uk) following the procedure modified by Caballero et al. (2008). The procedure to identify outlier loci is based on the assumption that loci under selection exhibit higher or lower $F_{\mathrm{ST}}$ values than the majority of neutral markers. DFDIST initially calculates empirical $F_{\mathrm{ST}}$ values for each locus and, from the empirical distribution, the trimmed mean $F_{\mathrm{ST}}$ is determined by removing the highest and lowest $30 \%$ observed in the empirical dataset. The software performs a coalescent simulation (50000 realizations) to generate data sets with a mean $F_{\mathrm{ST}}$, which equals the trimmed mean $F_{\mathrm{ST}}$ to obtain significant values that are higher or lower than the quantile limits $(5,50$ and 95\%). Loci with higher or lower $F_{\mathrm{ST}}$ values were considered under directional and balancing selection, respectively, and were, as outliers, excluded from the subsequent analysis.

Population differentiation was assessed by a hierarchical analysis of molecular variance (AMOVA), using Arlequin 3.0 (Excoffier et al., 2005) clustering the samples in different ways according to their geographic location. This analysis allowed to verify the partitioning of genetic variation among populations on the whole and within and among the groups generated, the last value reporting the correspondent fixation indices: $\Phi_{\mathrm{ST}}$ (the average within-populations within a group), $\Phi_{\mathrm{SC}}$ (the average among-populations within a group) and $\Phi_{\mathrm{CT}}$ (among groups).

Population differentiation was also inferred using the Bayesian approach, as implemented in the Structure software (Pritchard et al., 2000). This software was used to examine the most likely number of distinct genetic clusters $(K)$, assigning individuals to populations and to identify migrants and admixed individuals. Ten replicates for every value of $K$ were done, with $K$ ranging from 1 to 8 (burning length 100000 ). The true number of genetic clusters, $K$, is commonly identified 
as that with the highest posterior probability $(P(X \mid K))$, but as an increase in the probability values could lead to an overestimation of the number of genetic clusters, the procedure suggested by Evanno et al. (2005) was used to search for the lowest number of $K$ based on the second order rate of variation of $\ln P(D)$.

Subsequently, the Doh assignment test calculator (available online at http:// www2.biology.ualberta.ca/jbrzusto/Doh.php) was used to test whether individuals could be assigned to the samples from which they had been sampled. This software identifies genotypes of individuals from several populations and determines the population of origin for each individual, by using an assignment index, which is associated to the highest probability (Paetkau et al., 1995).

\section{RESULTS}

A total of 145 AFLP polymorphic loci were scored in 236 specimens of Aristeus antennatus. Within-population Nei gene diversity, $H_{\mathrm{E}}$, ranged from 0.288 to 0.392 (table II). Total gene diversity, $H_{\mathrm{T}}$, was 0.361 ; the average gene diversity, $H_{\mathrm{S}}$, was 0.340; and the percentage contributions of $\operatorname{Var} \mathrm{I}, \operatorname{Var} \mathrm{L}$ and $\operatorname{Var} \mathrm{P}$ to the variance of $H_{\mathrm{S}}$ were $1.50,6.95$ and $91.55 \%$, respectively, thereby demonstrating that the greater part of gene diversity was attributed to variation within-populations.

The analysis conducted with DFDIST software identified two different loci out of the 145 , polymorphic at the $95 \%$ confidence level. When the detected outliers were excluded, the neutral dataset was used to conduct a hierarchical AMOVA. This analysis was performed in different ways: clustering the samples "all together" (analysis $1_{\mathrm{AFLP}}$, table III) and clustering samples into groups coherent

TABLE II

AFLP analysis: genetic diversity data of Aristeus antennatus (Risso, 1816) based on the Lynch \& Milligan (1994) method

\begin{tabular}{lcccc}
\hline Site location & PLP $(0.05)$ & $H_{\mathrm{E}}$ & $\operatorname{VarI}(\%)$ & $\operatorname{VarL}(\%)$ \\
\hline ATL & 93.4 & 0.321 & 12.7 & 87.3 \\
CA & 97.5 & 0.327 & 45.8 & 54.2 \\
SR & 97.5 & 0.392 & 18.2 & 81.8 \\
SM & 94.2 & 0.322 & 24.4 & 75.6 \\
SW-SA & 100.0 & 0.378 & 22.0 & 78.0 \\
NE-SA & 92.6 & 0.305 & 15.3 & 84.7 \\
TE & 81.0 & 0.288 & 8.3 & 91.7 \\
SS & 97.5 & 0.386 & 18.4 & 81.6 \\
\hline
\end{tabular}

PLP, proportion of polymorphic loci within-populations at levels of $5 \%$; $H_{\mathrm{E}}$, gene diversity withinpopulation; VarI, the percentage of variance attributed to individuals; VarL, percentage of variance attributed to loci. 


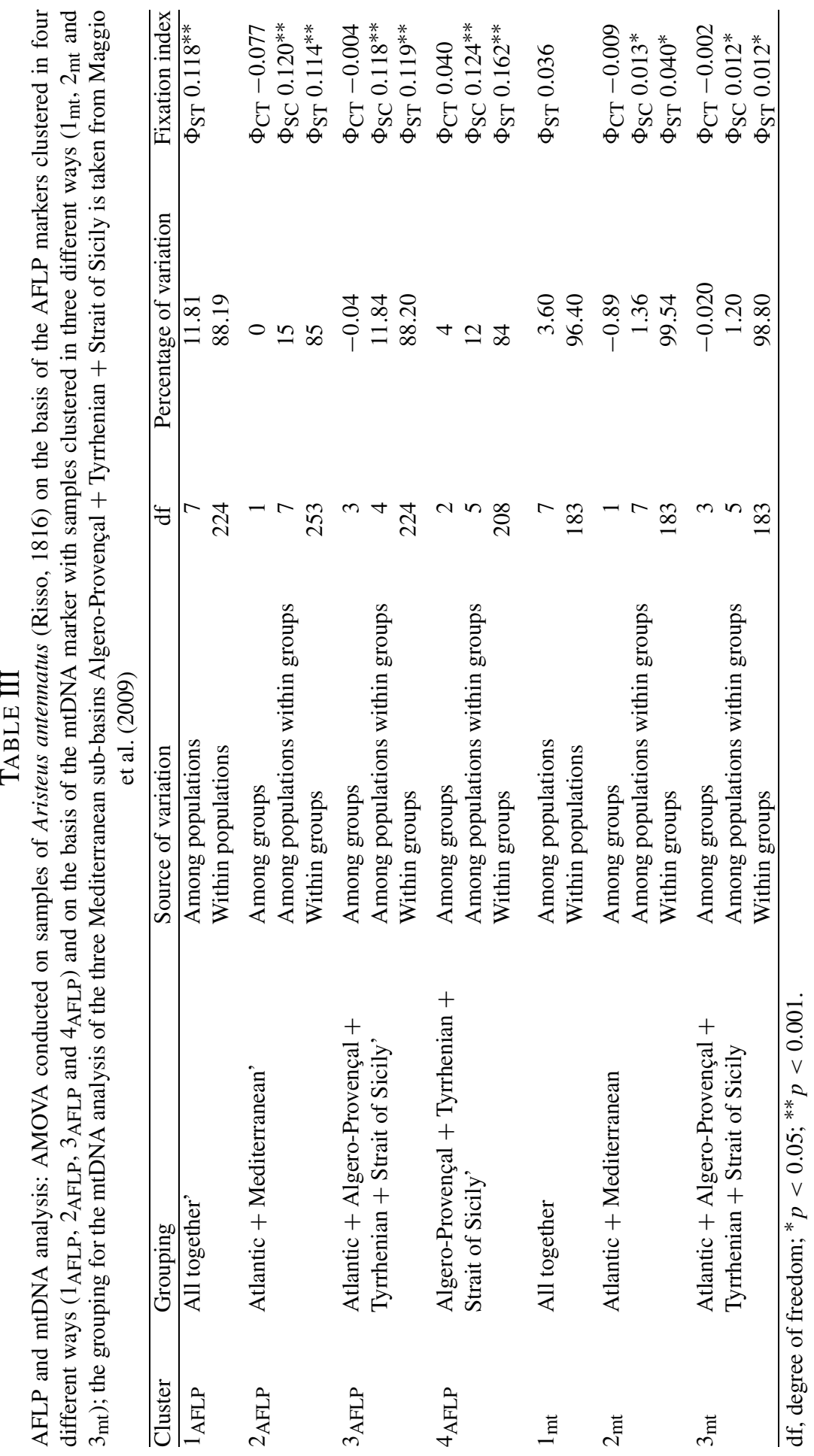


with their geographical location in order to understand where the observed genetic variation lay. The first grouping was 'Atlantic + Mediterranean' (analysis $2_{\mathrm{AFLP}}$, table III). Subsequently, the samples were pooled into four groups: the three Mediterranean sub-basins and the Atlantic ocean, 'Atlantic + Algero-Provençal + Tyrrhenian + Strait of Sicily' (analysis $3_{\mathrm{AFLP}}$, table III). Finally, the Mediterranean samples were grouped into the three sub-basins 'Algero-Provençal + Tyrrhenian + Strait of Sicily', excluding the Atlantic sample (analysis $4_{\mathrm{AFLP}}$, table III). AMOVA results revealed that the overall genetic variation among-populations which were grouped 'all together' in analysis $1_{\mathrm{AFLP}}$ was lower $(11.81 \%)$ than within-populations $(88.19 \%)$ though the fixation index proved to be significant $\left(\Phi_{\mathrm{ST}}=0.118 ; p<0.001\right)$. The genetic variation between the Atlantic and Mediterranean samples in analysis $2_{\mathrm{AFLP}}$ was found to be not significant $\left(\Phi_{\mathrm{CT}}=\right.$ -0.007 ; N.S.), indicating that genetic variation is not associated with the transition between the Atlantic Ocean and the Mediterranean Sea but rather to the variation found among populations within groups (15\% of genetic variation) and within populations $(85 \%)$.

Subsequently, when the samples were grouped into four groups ('Atlantic + Algero-Provençal + Tyrrhenian + Strait of Sicily'), the greater portion of the genetic variation was found within groups $(88.2 \%)$, reporting significant fixation indices $\left(\Phi_{\mathrm{ST}}=0.119 ; p<0.001\right)$; no genetic differentiation was detected among groups $\left(\Phi_{\mathrm{CT}}=-0.004\right.$; N.S.). Finally, the analysis $4_{\mathrm{AFLP}}$ revealed no differentiation among the three Mediterranean sub-basins as was evident by the non-significant fixation index ( $\Phi_{\mathrm{CT}}=0.04$; N.S.) (table III). This is in accordance with the previous results obtained with the same samples from Maggio et al. (2009) using mtDNA. The three clustering methods proved that the high value of genetic variation is not due to differences at group level but at population and individual levels.

Confirming our results, the Bayesian analysis conducted with Structure software demonstrated the absence of genetic differentiation between the Atlantic and Mediterranean populations. The two modes in the graph of $\Delta K$ vs. $K$ were observed for $K=2(\log =-22879)$ and $K=5(\log =-20995)$. When $K=2$, the separation into two genetic clusters negated any geographical correspondence with the Atlantic-Mediterranean subdivision and revealed a high degree of membership to the first cluster for the Mediterranean samples (table IV and fig. 1). When $K=5$, the average proportion of membership was low ( $q<$ 0.70) for all samples, indicating the presence of admixed individuals (table IV). The putative migrants identified by the Bayesian-based assignment method were distributed throughout all our samples and particularly the samples with numerous specimens considered as migrants were SM, SW-SA and TE. 
TABLE IV

AFLP analysis: proportion of membership of each pre-defined population in the most probable genetic clusters of Aristeus antennatus (Risso, 1816) identified in the Bayesian analysis, as suggested by Evanno et al. (2005)

\begin{tabular}{lcccccccr}
\hline & \multicolumn{2}{c}{$K=2$} & & \multicolumn{5}{c}{$K=5$} \\
\cline { 2 - 5 } \cline { 6 - 8 } & 1 & 2 & & 1 & 2 & 3 & 4 & 5 \\
\hline ATL & 0.592 & 0.408 & & 0.355 & 0.055 & 0.073 & 0.448 & 0.069 \\
CA & 0.532 & 0.468 & & 0.514 & 0.080 & 0.013 & 0.365 & 0.028 \\
SR & 0.900 & 0.100 & & 0.056 & 0.482 & 0.062 & 0.334 & 0.067 \\
SM & 0.660 & 0.340 & & 0.192 & 0.031 & 0.077 & 0.145 & 0.555 \\
SW-SA & 0.791 & 0.209 & & 0.147 & 0.362 & 0.078 & 0.315 & 0.099 \\
NE-SA & 0.628 & 0.372 & & 0.146 & 0.067 & 0.028 & 0.063 & 0.695 \\
TE & 0.698 & 0.302 & & 0.167 & 0.267 & 0.474 & 0.050 & 0.042 \\
SS & 0.859 & 0.141 & & 0.088 & 0.036 & 0.065 & 0.629 & 0.182 \\
\hline
\end{tabular}

In the assignment analysis conducted with Doh software, 151 of the total of 236 specimens analysed were assigned to the sampling population, corresponding to $65 \%$ of correct assignment. Specifically, there was a high assignment success in ATL, NE-SA, TE, SS and CA (ranging from 73\% to 89\%) and a low assignment success, and consequently a high number of putative migrants, in SR, SM and SW-SA (table V).

The mitochondrial control region fragment was sequenced in the sample from the Atlantic and showed high haplotype diversity (0.934), and similar to the Mediterranean samples (Maggio et al., 2009); nucleotide diversity was low for both the Atlantic (0.019) and Mediterranean area (see Maggio et al., 2009). AMOVA results based on mtDNA were in accordance with the AFLP results, as reported in table III: the partitioning of genetic variation obtained by clustering the samples into two groups, the Atlantic and Mediterranean, revealed that the

TABLE V

AFLP analysis: results of the Doh assignment test scored in Aristeus antennatus (Risso, 1816)

\begin{tabular}{lrrrrrrrr}
\hline & \multicolumn{7}{c}{ Population assigned } \\
\cline { 2 - 8 } & ATL & CA & SR & SM & NE-SA & SW-SA & TE & SS \\
\hline ATL & 41 & 1 & 2 & 0 & 0 & 1 & 0 & 1 \\
CA & 2 & 23 & 1 & 0 & 0 & 1 & 1 & 2 \\
SR & 0 & 0 & 15 & 1 & 0 & 3 & 1 & 10 \\
SM & 0 & 3 & 1 & 5 & 6 & 0 & 0 & 0 \\
SW-SA & 2 & 1 & 4 & 1 & 1 & 10 & 2 & 9 \\
NE-SA & 0 & 3 & 0 & 2 & 22 & 0 & 0 & 0 \\
TE & 0 & 2 & 3 & 0 & 0 & 3 & 22 & 0 \\
SS & 1 & 3 & 1 & 0 & 0 & 1 & 0 & 22 \\
\hline
\end{tabular}


two geographical areas were not significantly different $\left(\Phi_{\mathrm{CT}}=-0.009\right.$; N.S. $)$ and the greatest variation was among-populations within groups and withinpopulations (table III). Even clustering the samples into the four 'Atlantic + Algero-Provençal + Tyrrhenian + Strait of Sicily' groups did not account for significant differences among groups $\left(\Phi_{\mathrm{CT}}=-0.0002 ;\right.$ N.S. $)$.

\section{DISCUSSION}

Aristeus antennatus is a species with a wide geographical distribution and may, therefore, be composed of distinct genetic units as previous mitochondrial results had demonstrated on a macro-geographical scale (i.e., Mediterranean vs. Indian Ocean in Fernández et al., 2011). However, a low degree of differentiation in smaller spatial areas, such as those which cover the Mediterranean Sea, was found by using mtDNA (Maggio et al., 2009; Roldán et al., 2009).

In the present work, AFLP and the mitochondrial dataset showed congruent patterns of low genetic differentiation among the samples analysed, coupled with a high genetic variation within-populations clearly shown along the Mediterranean samples.

The low degree of genetic differentiation among Mediterranean populations of the blue and red shrimp may be a consequence of the mobility pattern of the species. Specifically, vertical and horizontal displacements of adults have been reported in relation to the spatio-temporal variation of the trophic resources in response to the action of chemical and physical factors in deep-sea habitats (Tudela et al., 2003; Cartes et al., 2008). Vertical mixing of different stocks has been recently demonstrated by analysing the genetic structure of A. antennatus along a depth gradient, proving that the gene flow is high and that the deeper living stocks are not isolated from those in the higher strata (Sardà et al., 2010; Cannas et al., 2012). Deep-water circulation and turbulent mixing phenomena, associated with the migration events of $A$. antennatus, seem to promote some degree of gene flow (Maggio et al., 2009; Roldán et al., 2009; Sardà et al., 2010; Fernández et al., 2011).

Besides, the present data provide evidence for a genetic similarity between the eastern North Atlantic Ocean and the Mediterranean basin, thus supporting the occurrence of gene flow between the two areas. With reference to the AMOVA, grouping the population according to their geographical location, 'Atlantic + Mediterranean' (table III), and to the Structure results obtained from AFLP (fig. 1) an absence of any genetic break between the Atlantic and Mediterranean is evident. Furthermore, the Bayesian analysis (table IV) and the Doh assignment test (table V) similarly supported the presence of migrants (population admixture) as 
well among the various Mediterranean populations as between the Atlantic Ocean and the Mediterranean Sea.

The area of transition from the eastern Atlantic to the western Mediterranean involves inflowing Atlantic water, which forms two almost permanent anticyclonic gyres from Almeria in Spain to Oran in Morocco (the Almeria-Oran Front, AOF). This front has been considered a barrier to various species for displacements of larvae and adults (Patarnello et al., 2007). However, the inflow of enriched superficial water and a down-welling process determine high levels of nutrients and concentrations of small organisms, which have made this area a favourable feeding and recruitment ground, and a larval retention area for some other species (Caddy, 1993; Sanchez-Vidal et al., 2004).

Such characteristics could render the area suitable for the mixing of the pelagic and bentho-pelagic stages of A. antennatus and we may assume that the transition Atlantic-Mediterranean area cannot be considered a physical barrier to gene flow but rather an area in which the adults and the juveniles can mix horizontally and vertically along the water column in relation to the availability of trophic resources.

This study has provided a further assessment of the genetic population structure of $A$. antennatus, because nuclear results corroborated previous studies, and did not describe strong break-points in the populations of the species inhabiting the Mediterranean Sea.

As one of the most important deep-sea resources and considering the demonstrable and tight link between species and environmental features, A. antennatus should be further investigated as a model species in the light of the present-day climate warming. Climate changes strongly influence the hydrography of marine ecosystems and could, therefore, correlate with the change in population dynamics and population structure of $A$. antennatus, as suggested by several authors (Cartes, 1994; Company et al., 2008; Guijarro et al., 2008; Maynou, 2008; Lo Brutto et al., 2011). Additional samples from other Atlantic areas and more data regarding the influence of environmental features on the dynamics of populations are required to improve the documentation regarding the genetic differentiation of the species. An exhaustive understanding of population genetic structure will further be of fundamental importance in managing and conserving this species, taking into consideration the paucity of knowledge on the effects of increased deep-water trawling on benthic faunas as reported in Danovaro et al. (2010).

\section{ACKNOWLEDGEMENTS}

We are grateful to C. Silva from INRB/L-IPIMAR (Lisbon, Portugal) for collecting samples of Aristeus antennatus from Portuguese coasts. This research was partially supported by "Fondi d'Ateneo ex 60\%" and POR-Sicilia No. 0062. 


\section{REFERENCES}

Apostolidis, A. P., M. T. Stoumboudi, E. Kalogianni, G. Cote \& L. Bernatchez, 2011. Genetic divergence among native trout Salmo trutta populations from southern Balkans based on mitochondrial DNA and microsatellite variation. Journal of Fish Biology, 79: 1950-1960.

Arculeo, M., G. Payen, A. Cuttitta, G. Galioto \& S. Riggio, 1995. A survey of the ovarian maturation in a population of Aristeus antennatus (Crustacea Decapoda). Animal Biology, 4: $13-18$.

Arculeo, M., S. Vitale, L. Cannizzaro \& S. Lo Brutto, 2011. Growth parameters and population structure of Aristeus antennatus (Decapoda, Penaeidae) in the south Tyrrhenian Sea (southern coast of Italy). Crustaceana, 84: 1099-1109.

Beaumont, M. A. \& D. J. BALding, 2004. Identifying adaptive genetic divergence among populations from genome scans. Molecular Ecology, 13: 969-980.

Beaumont, M. A. \& R. A. Nichols, 1996. Evaluating loci for use in the genetic analysis of population structure. Proceedings of the Royal Society B, 263: 1619-1626.

Caballero, A., H. Quesada \& E. Rolan-Alvarez, 2008. Impact of Amplified Fragment Length Polymorphism size homoplasy on the estimation of the population genetic diversity and the detection of selective loci. Genetics, 179: 539-554.

CADDY, J. F., 1993. Toward a comparative evaluation of human impacts on fishery ecosystems of enclosed and semi enclosed seas. Reviews in Fisheries Science, 1: 57-95.

$\ldots$, 1999. Fisheries management in the twenty-first century: will new paradigms apply? Reviews in Fish Biology and Fisheries, 9: 1-43.

Cannas, R., F. Sacco, M. C. Follesa, A. Sabatini, M. Arculeo, S. Lo Brutto, T. Maggio, A. M. Deiana \& A. CAU, 2012. Genetic variability of the blue and red shrimp Aristeus antennatus in the western Mediterranean Sea inferred by DNA microsatellite loci. Marine Ecology, 33: 350-363.

CARTES, J. E., 1994. Influence of depth and season on the diet of the deep-water aristeid Aristeus antennatus along the continental slope $(400 \mathrm{~m}$ to $2300 \mathrm{~m})$ in the Catalan Sea (western Mediterranean). Marine Biology, 120: 639-648.

Cartes, J. E., T. Madurell, E. Fanelli \& J. L. Lopez-Jurado, 2008. Dynamics of suprabenthos-zooplankton communities around the Balearic Islands (NW Mediterranean): influence of environmental variables and effects on higher trophic levels. Journal of Marine Systems, 71: 316-335.

Cau, A., A. Carbonell, M. C. Follesa, A. Mannini, G. Norrito, L. Orsi Relini, C. Y. Politou, S. RAgonese \& P. Rinelli, 2002. MEDITS-based information on the deepwater red shrimps Aristaeomorpha foliacea and Aristeus antennatus (Crustacea: Decapoda: Aristeidae). Scientia Marina, 66: 103-124.

Company, J. B., P. Puig, F. Sardà, A. Palanques, M. Latasa \& R. Scharek, 2008. Climate influence on deep sea populations. PLoS ONE, 3: 1431.

Crosnier, A., 1978. Crustacés Décapodes Péńeides Aristeidae (Benthesicyminae, Aristeinae, Solenocerinae). Faune de Madagascar, 46: 1-197.

Danovaro, R., J. B. Company, C. Corinaldesi, G. D’Onghia, B. Galil, C. Gambi, A. J. Gooday, N. Lampadariou, G. M. Luna, C. Morigi, K. Olu, P. Polymenakou, E. Ramirez-Llodra, A. Sabbatini, F. Sardà, M. Sibuet \& A. Tselepides, 2010. Deep-sea biodiversity in the Mediterranean Sea: the known, the unknown, and the unknowable. PLOS ONE, 5: 11832.

Demestre, M. \& J. Lleonart, 1993. Population dynamics of Aristeus antennatus (Decapoda: Dendrobranchiata) in the Northwestern Mediterranean. Scientia Marina, 57: 183-189.

Evanno, G., S. Regnaut \& J. Goudet, 2005. Detecting the number of clusters of individuals using the software structure: a simulation study. Molecular Ecology, 14: 2611-2620. 
Excoffier, L., G. LAVAL \& S. SchneIder, 2005. Arlequin vers 3.0: and integrated software package for population genetic data analysis. Evolutionary Bioinformatics Online, 1: 47-50.

Fernández, M. V., S. Heras, F. Maltagliati, A. Turco \& M. I. Roldán, 2011. Genetic structure in the blue and red shrimp Aristeus antennatus and the role played by hydrographical and oceanographical barriers. Marine Ecology Progress Series, 421: 163-171.

Garoia, F., I. GuARniero, D. Grifoni, S. Marzola \& F. Tinti, 2007. Comparative analysis of AFLPs and SSRs efficiency in resolving population genetic structure of Mediterranean Solea vulgaris. Molecular Ecology, 16: 1377-1387.

Guijarro, B., E. Massutí, J. Moranta \& P. Díaz, 2008. Population dynamics of the red shrimp Aristeus antennatus in the Balearic Islands (western Mediterranean): short spatiotemporal differences and influence of environmental factors. Journal of Marine Systems, 71: 385-402.

HolthUis, L. B., 1980. FAO species catalogue. Shrimps and prawns of the world. An annotated catalogue of species of interest to fisheries. FAO Fisheries Synopses, 125, Vol. 1. (FAO, Rome).

KAPIRIS, K. \& M. THESSALOU-LEGAKI, 2001. Sex-related variability of rostrum morphometry of Aristeus antennatus (Decapoda: Aristeidae) from the Ionian Sea (eastern Mediterranean, Greece). Hydrobiologia, 449: 123-130.

— — \& _ - 2006. Comparative fecundity and oocyte size of Aristaeomorpha foliacea and Aristeus antennatus in the Greek Ionian Sea (E. Mediterranean) (Decapoda: Aristeidae). Acta Zoologica, 87: 239-245.

Librado, P. \& J. Rozas, 2009. DnaSP v5: a software for comprehensive analysis of DNA polymorphism data. Bioinformatics, 25: 1451-1452.

Lo Brutto, S., M. ARCuleo \& W. S. Grant, 2011. Climate change and population genetic structure of marine species. Chemistry and Ecology, 27: 107-119.

Lo Brutto, S., M. Arculeo \& N. PARrinello, 2004. Congruence in genetic markers used to describe different Mediterranean and Atlantic populations of European hake (Merluccius merluccius L. 1758). Journal of Applied Ichthyology, 20: 81-86.

Lo Brutto, S., N. Hristovski \& M. ArCuleo, 2010. Genetic divergence between morphological forms of brown trout Salmo trutta L. in the Balkan region of Macedonia. Journal of Fish Biology, 76: 1220-1227.

LU, R. H., T. QIU, C. M. XIANG, H. XIE \& J. ZHANG, 2000. RAPD and AFLP techniques for the analysis of genetic relationships in two genera of Decapoda. Crustaceana, 73: 1027-1036.

LYNCH, M. \& B. G. Milligan, 1994. Analysis of population genetic structure with RAPD markers. Molecular Ecology, 3: 91-99.

Maggio, T., S. Lo Brutto, R. Cannas, A. M. Deiana \& M. Arculeo, 2009. Environmental features of deep-sea habitats linked to the genetic population structure of a crustacean species in the Mediterranean Sea. Marine Ecology, 30: 354-365.

Maiorano, P., L. Sion, R. Carlucci, F. Capezzuto, A. Giove, G. Costantino, M. PAnZA, G. D'Onghia \& A. TURSi, 2010. The demersal faunal assemblage of the northwestern Ionian Sea (central Mediterranean): current knowledge and perspectives. Chemistry and Ecology, 26: 219-240.

MAYNOU, F., 2008. Environmental causes of the fluctuations of red shrimp (Aristeus antennatus) landings in the Catalan Sea. Journal of Marine Systems, 71: 294-302.

Morato, T., R. Watson, T. J. Pitcher \& D. Pauly, 2006. Fishing down the deep. Fish and Fisheries, 7: 24-34.

NeI, M., 1987. Molecular evolutionary genetics. (Columbia University Press, New York, NY).

Paetkau, D., W. Calvert, I. Sterling \& C. Strobeck, 1995. Microsatellite analysis of population structure in canadian polar bears. Molecular Ecology, 4: 347-354.

Papaconstantinou, C. \& K. KapiRis, 2001. Distribution and population structure of the red shrimp (Aristeus antennatus) on an unexploited fishing ground in the Greek Ionian Sea. Aquatic Living Resources, 14: 303-312. 
Patarnello, T., F. A. M. J. Volckaert \& R. Castilho, 2007. Pillars of Hercules: is the atlantic-mediterranean transition a phylogeographical break? Molecular Ecology, 16: 44264444.

Pritchard, J. K., M. Stephens \& P. Donnelly, 2000. Inference of population structure using multilocus genotype data. Genetics, 155: 945-959.

Ragonese, S. \& M. L. BiAnChini, 1996. Growth, mortality and yield-per-recruit of the deepwater shrimp Aristeus antennatus (Crustacea-Aristeidae) of the Strait of Sicily (Mediterranean Sea). Fisheries Research, 26: 125-127.

Ribeiro-CAscalho, A. \& I. ARrobas, 1982. Aristeus antennatus Risso, 1816: some considerations about its biology and fishery in portuguese water. ICES Journal of Marine Science, 6 123-133.

RoberTs, C. M., 2002. Deep impact: the rising toll of fishing in the deep sea. Trends in Ecology and Evolution, 17: 242-245.

Roldán, M. I., S. Heras, R. Patellani \& F. Maltagliati, 2009. Analysis of genetic structure of the red shrimps Aristeus antennatus from the western Mediterranean employing two mitochondrial regions. Genetica, 136: 1-4.

Sanchez-Vidal, A., A. Calafat, M. Canals \& J. Fabres, 2004. Capitol 2: particle fluxes in the Almeria-Oran front: control by coastal upwelling and sea surface circulation. Journal of Marine System, 52: 89-106.

SARdÀ, F., C. BAS, M. I. RoldÁn, C. Pla \& J. LleonarT, 1998. Enzymatic and morphometric analyses in mediterranean populations of the rose shrimp Aristeus antennatus (Risso 1816). Journal of Experimental Marine Biology and Ecology, 221: 131-144.

SARDÀ, F. \& J. E. CARTES, 1997. Morphological features and ecological aspects of early juvenile specimens of the aristeid shrimp Aristeus antennatus (Risso, 1816). Marine and Freshwater Research, 48: 73-77.

SARdÀ, F., J. E. CARTES \& W. Norbis, 1994. Spatio-temporal structure of the deep-water shrimp Aristeus antennatus Risso, 1816 (Decapoda: Aristeidae) population in the western Mediterranean. Fishery Bulletin, 92: 599-607.

Sardà, F., G. D’Onghia, C. Y. Politou, J. B. Company, P. Maiorano \& K. Kapiris, 2004. Deep-sea distribution, biological and ecological aspects of Aristeus antennatus (Risso, 1816) in the western and central Mediterranean Sea. Scientia Marina, 68: 117-127.

SARdÀ, F., M. I. RoldÁn, S. Heras \& F. Maltagliati, 2010. Influence of the genetic structure of the red and blue shrimp, Aristeus antennatus (Risso, 1816), on the sustainability of a deepsea population along a depth gradient in the western Mediterranean. Scientia Marina, 74: 569575.

Tudela, S., F. SARdÀ, F. MAYnou \& M. Demestre, 2003. Influence of submarine canyons on the distribution of the deep-water shrimp (Aristeus antennatus, Risso 1816) in the northwestern Mediterranean. Crustaceana, 76: 217-225.

Vekemans, X., T. Beauwens, M. Lemaire \& I. Roldan-Ruiz, 2002. Data from amplified fragment length polymorphism (AFLP) markers show indication of size homoplasy and a relationship between degree of homoplasy and fragment size. Molecular Ecology, 11: 139151.

Vos, P., R. Hogers, M. Bleeker, M. Reijan, T. van de Lee, M. Hornes, A. Frijters, J. Pot, J. Peleman, M. Kuiper \& M. Zabeau, 1995. AFLP: a new technique for DNA fingerprinting. Nucleic Acid Research, 23: 4407-4414.

Weetman, D., A. Ruggiero, S. Mariani, P. W. Shaw, A. R. Lawler \& L. Hauser, 2007. Hierarchical population genetic structure in the commercially exploited shrimp Crangon crangon identified by AFLP analysis. Marine Biology, 151: 565-575. 
Zhivotovsky, L. A., 1999. Estimating population structure in diploids with multilocus dominant DNA markers. Molecular Ecology, 8: 907-913.

First received 7 June 2012.

Final version accepted 9 July 2012. 